\title{
NFUD symposium 2018 i Stavanger
}

NFUD har gleden av å ønske deg hjertelig velkommen til årets ultralyd-symposium 18. - 20. april 2018i Stavanger. Symposiet finner sted på Clarion Hotel Energy.

Vi har jobbet med å sette sammen et 3-dagers program der vi håper alle vil finne forelesninger og praktiske øvelser av interesse. Programmet starter onsdag 18. april med en fellessesjon med viktig basal ultralydkunnskap om sikkerhet og knottologi. Etter lunsj starter egne parallellsesjoner med fagspesifikke foredrag og praktisk ultralyd trening på friske frivillige, samt muligheten for å se etter patologi ved bruk av innovative ultralydsimulatorer. Hovedgruppene er muskelskjelett og akutt/allmennmedisin. Den praktiske treningen fortsetter på torsdag 19. april frem til lunsj. Vi håper dette vil rekruttere flere nye brukere av ultralyd, men treningen vil være en fin repetisjon også for mange erfarne brukere. Gynekologi og obstetrikk har som alltid egne parallellsesjoner med forelesninger og live-demonstrasjoner.

Vi har også i år med oss utenlandske og norske forelesere for å belyse spennende fagområder. Av sosialt kan vi onsdag kveld invitere til "get together" samling på hotellet med litt sprudlende og finger-mat før vi torsdag kveld slår på stortromma og inviterer til festmiddag med prisutdelinger. Fredagen avsluttes med en spennende fellessesjon om "Fremtidens ultralyd» og paneldebatt: «Hvem skal gjøre hva med ultralyd». I panelet deltar flere faggrupper.

Det settes ingen endelig påmeldingsfrist, men alle oppfordres til å melde seg på innen 09. mars 2018 for å være sikret å få hotellrom.

Frist for innsending av frie foredrag og for å søke forskningsstipend på kr. 10.000,- er 15. mars.


Onsdag 18. april

$10.00-10.20$ Registrering og kaffe 10.20 - 10.30 Velkommen

Kari Utne

Fellessesjon

10.30 - 10.50 Ultralyd: Farlig støy eller harmoni?

$10.50-11.10$ Knottologi/bildeoptimalisering

Kathinka Retz

$11.10-11.30 \quad$ Pause

11.30 - 12.30 Frie foredrag / kasuistikk

12.30 - 13.30 Lunsj

Parallelle sesjoner

13.30 - 17.00 Praktisk ultralydtrening (hands-on)

\begin{tabular}{|l|l|l|}
\hline Tid & Muskelskjelett & Ultralyd i legevakt og akuttmottak \\
\hline $13.30-14-30$ & $\begin{array}{l}\text { Hofteregion v/ fys. med. Herlof Harstad } \\
\text { og revmatolog Hilde Berner Hammer }\end{array}$ & Tungpust \\
\hline $14.45-15.45$ & $\begin{array}{l}\text { Pleosacralledd } \\
\text { v/ revmatolog Vivi Bakkeheim }\end{array}$ & Hovent og rødt ben \\
\hline $16.00-17.00$ & $\begin{array}{l}|c| \\
\text { Ankel v/ radiolog Annja Viset } \\
\text { og revmatolog Hilde Berner Hammer }\end{array}$ & Hypotensiv \\
\hline
\end{tabular}

13.30 - 17.00 Gynekologi/obstetrikk: foredrag og demonstrasjon

\begin{tabular}{|c|c|c|}
\hline $\begin{array}{l}13.30-14-15 \\
13.30-14-15\end{array}$ & $\begin{array}{l}\text { Systematisk undersøkelse } 12 \text {-ukers scan } \\
\text { Normal og abnormal utvikling av embryo }\end{array}$ & $\begin{array}{l}\text { Aurora Røset } \\
\text { Harm-Gerd Blaas }\end{array}$ \\
\hline \multicolumn{3}{|c|}{ Pause (15 min) } \\
\hline $\begin{array}{l}15.00-15.15 \\
15.15-15.35 \\
15.35-16.00\end{array}$ & $\begin{array}{l}\text { Live scan } 12 \text { uker } \\
\text { Missed abortion / sikker diagnose } \\
\text { Extrauterin pregnancy / pregnancy of unknown location (PUL) }\end{array}$ & Claudia Heien \\
\hline \multicolumn{3}{|c|}{ Pause (15 min) } \\
\hline $\begin{array}{l}16.15-16.45 \\
16.45-17.00\end{array}$ & $\begin{array}{l}\text { Non-Invasiv Prenatal Test (NIPT) } \\
\text { 3D ultralyd }\end{array}$ & Torbjørn Eggebø \\
\hline
\end{tabular}

17.30 - 19.00 Generalforsamling

19.00 - 20.00 Get-together Cocktail Party

\section{Torsdag 19. april}

Fellessesjon

08.30 - 09.00 Fremtidens ultralyd

09.00 - 10.00 Frie foredrag/kasuistikk

Solveig Fadnes

$0.00-11.20$ Pause

Parallelle sesjoner

10.20 - 12.30 Praktisk ultralyd (hands-on):

\begin{tabular}{|l|l|l|}
\hline Tid & Muskelskjelett/idrettsmedisin & Akuttmedisin og allmennmedisin \\
\hline $10.20-11.20$ & Skulder v/ radiolog Mehdi Behzadi & Brystsmerter \\
\hline $11.35-12.30$ & $\begin{array}{l}\text { Skulder v/ fys. med. Herlof Harstad } 15 \mathrm{~min}) \\
\text { og revmatolog Vivi Bakkeheim }\end{array}$ & Magesmerter \\
\hline
\end{tabular}


Frie foredrag skal sendes til frieforedrag@ nfud.no. Nytt av året er pris for beste kasuistikk på kr. 5000 NOK. Beste frie foredrag med forskning premieres med kr. 10000 NOK.

Vi minner også om NFUD's forskningsstipend som i år er på kr. 10000 NOK. Alle NFUD medlemmer som driver med eller planlegger et ultralyd-relatert forskningsprosjekt kan søke. En kortfattet prosjektbeskrivelse, og informasjon om hvordan pengene tenkes brukt, sendes til stipend@nfud.no.
10.20 - 12.30 Gynekologi/obstetrikk:

\begin{tabular}{|l|ll|}
\hline \begin{tabular}{l|l}
$10.20-10.40$ \\
$10.40-11.05$
\end{tabular} & $\begin{array}{l}\text { The current status of 3D ultrasound in gynecology } \\
\text { Ultrasound strategy in endometriosis/endometrioma in pregnancy } \\
11.05-11.25\end{array}$ & $\begin{array}{l}\text { Dina Ismail } \\
\text { Davor Jurkovic } \\
\text { Tina Tellum }\end{array}$ \\
\hline $\begin{array}{l}11.40-12.10 \\
12.10-12.30\end{array}$ & $\begin{array}{l}\text { Non-tubal/ ectopic pregnancy } \\
\text { "One-stop fertility workup with ultrasound" }\end{array}$ & $\begin{array}{l}\text { Davor Jurkovic } \\
\text { Tina Tellum }\end{array}$ \\
\hline
\end{tabular}

$12.30-13.30$ Lunsj.

13.30 - 14.30 Frie foredrag/kasuistikk

14.30 - 15.15 Pause / besøk utstilling

Parallelle sesjoner

15.15 - 17.00 Muskel/skjelett

15.15 - 15.50 Skulder-diagnostikk Mehdi Behzadi

15.50 - 16.20 Skulder-injeksjonsteknikk Herlof Harstad

16.20 - 16.30 Pause

16.30 - 17.00 Bløtvevstumorer

Mehdi Behzadi

$15.15-17.00$ Obstetrikk og gynekologi

15.15 - 15.50 Basal neurosonografi

16.10 - 16.20 Pause

16.20 - 16.45 Posterior fossa anomalier

Bodil Hvingel

16.45 - 17.00 Live scan

15.15 - 17.00 Radiologi/indremedisin/allmennmedisin

$15.15-15.35$ Cholecystitt

16.00 - 16.10 Pause

16.10 - 16.35 Den gule pasienten Kim Nylund

16.35 - 17.00 Ultralyd ved PBC og PSC $\quad$ Odd Helge Gilja

$19.30 \quad$ Aperitiff

20.00 Festmiddag med overrekkelse av forskningsstipend og pris for beste frie foredrag

\section{Fredag 20. april}

Fellessesjon

08.30 - 10.00 Tema: "Hvem skal gjøre hva med ultralyd?"

Tema: Sertifisering, retningslinjer, spesialisering

Deltakere: radiolog, allmennmedisin, jordmor, sonograf og anestesilege

08.30 - 08.45 Ultralyd i akuttmedisin

08.45 - 09.00 Ultralydundersøkelse hos jordmor

09.00 - 09.15 Bildediagnostikk og ultralyd ved radiolog

09.15 - 09.30 Sonografens rolle

09.30 - 09.45 Allmennmedisinerens rolle

Kari Utne

Åse Tangerud

Viktoria Vatsvåg

09.45 - 10.15 Pause

Morten Glasø

Paneldebatt

$10.15-12.00 \quad$ Moderator: Erik Andreas Torkildsen

Deltakere: Nils Petter Oveland, Kari Utne, Åse Tangerud, Viktoria Vatsvåg og Morten Glasø

$12.00-12.15$ Avslutning

$12.15-13.30$ Lunsj

For nærmere informasjon og påmelding: www.nfud.no 